Georgia State University

ScholarWorks @ Georgia State University

$1-14-2022$

\title{
Revisiting the theory of revenue diversification: Insights from an empirical analysis of municipal budgetary solvency
}

\author{
Benedict Jimenez \\ G, bjimenez@gsu.edu \\ Whitney Afonso \\ University of North Carolina at Chapel Hill, afonso@sog.unc.edu
}

Follow this and additional works at: https://scholarworks.gsu.edu/pmap_facpubs

Part of the Political Science Commons, and the Public Affairs, Public Policy and Public Administration Commons

\section{Recommended Citation}

Jimenez, Benedict and Afonso, Whitney, "Revisiting the theory of revenue diversification: Insights from an empirical analysis of municipal budgetary solvency" (2022). PMAP Publications. 30.

doi: 10.1111/pbaf.12309

This Article is brought to you for free and open access by the Department of Public Management and Policy at ScholarWorks @ Georgia State University. It has been accepted for inclusion in PMAP Publications by an authorized administrator of ScholarWorks @ Georgia State University. For more information, please contact scholarworks@gsu.edu. 
Published as: Jimenez, Benedict S. and Whitney Afonso. (2021) Revisiting the theory of revenue diversification: Insights from an empirical analysis of municipal budgetary solvency Public Budgeting and Finance. Firs published online as DOI:10.1111/pbaf.12309

Revisiting the Theory of Revenue Diversification: Insights from an Empirical Analysis of Municipal Budgetary Solvency

By

Benedict S. Jimenez

Associate Professor of Public Management and Policy

Andrew Young School of Policy Studies

Georgia State University

bjimenez@gsu.edu

and

Whitney Afonso

Associate Professor of Public Administration and Government

School of Government

University of North Carolina at Chapel Hill

afonso@sog.unc.edu 


\section{Applications for practice:}

- This study examines the relationship between tax and non-tax revenue diversification and government-wide budgetary solvency (structural budget balance). It is the first in the revenue diversification literature to consider the total revenues and costs of operating government and incorporates a broader base of tax and non-tax revenue sources including utilities.

- The results suggest that increased reliance on non-tax revenue sources, such as charges and fees, improves budgetary solvency.

- In contrast, we find evidence that increased diversification of tax instruments leads to poor budget outcomes.

- When financial managers and policymakers are considering adopting a new revenue source or expanding a current revenue stream, from a budgetary solvency standpoint, non-tax sources may be advantageous. 


\title{
Revisiting the Theory of Revenue Diversification: Insights from an Empirical Analysis of Municipal Budgetary Solvency
}

\begin{abstract}
How does revenue diversification shape the budgetary solvency of city governments? Previous studies informed by the public choice/fiscal illusion perspective suggest that diversification leads to unsustainable government expansion and budgetary imbalance. In contrast, the organizational adaptation/modern portfolio theory suggests that diversification enables government to prepare for external fiscal shocks. We use different measures of revenue diversification and rely on audited financial information to develop general fund-based and government-wide budgetary solvency measures for more than 500 midsized and large cities in the U.S. from 2006 to 2012. Addressing omitted variable bias, the results of the econometric analyses indicate that the type of diversification matters. Specifically, diversifying to non-tax sources improves budgetary solvency as indicated by higher government-wide operating ratio and reserves, whereas diversifying within the tax structure produces the opposite effects. The contradictory results point to the need to rethink current theories of diversification, which do not recognize the different ways that revenue structures can be broadened, and how these produce distinct effects on fiscal performance. We lay out the critical first step in clarifying and further developing a more nuanced theory by proposing three causal mechanisms outlining the pathways through which the types of diversification can influence budget outcomes.
\end{abstract}

Keywords: Revenue Diversification, Organizational Adaptation, Fiscal Illusion, Budgetary Solvency 


\section{INTRODUCTION}

The role of revenue diversification in promoting the fiscal health of governments continues to be a subject of intense debate in the literature. Most studies on revenue structure are informed by the public choice perspective, specifically the fiscal illusion hypothesis, which suggests that diversification causes citizens to underestimate their true tax burden, leading them to support higher levels of taxation and spending than they otherwise would (Buchanan 1967; Wagner 1976; Oates 1972; Dollery and Worthington 1996). In contrast, the organizational perspective in financial management, based on modern portfolio theory, suggests that a diverse revenue portfolio helps offset the negative effects of external environmental shocks on a city's fiscal health (Hendrick 2002, 2011; Carroll 2005, 2009).

In this study, we examine how revenue diversification influences budgetary solvency by focusing on U.S. municipalities with a population of 50,000 or more. Revenue diversification involves relying on different revenue sources and avoiding dependence on specific types of tax or non-tax sources (Suyderhood 1994; Carroll, Eger, and Marlowe 2003; Carroll 2005, 2009; Hendrick 2002; Hendrick and Crawford 2014). Budgetary solvency or structural budget balance - an important dimension of government fiscal health - means that "recurring (projected)

revenue matches or exceeds (expected) expenses" during a reporting period, which is typically a fiscal year (Johnson, Kioko, and Hildreth 2012, 84). Poor budgetary solvency is indicated by smaller and declining reserves culminating in deficits.

Revenue diversification has been linked to different fiscal outcomes. Studies focusing on spending or revenue levels offer mixed findings, with one concluding that diversification reduces expenditures (Carroll 2005), some reporting the opposite effect (Shi and Tao 2018; Hendrick and Degnan 2020), and another showing insignificant effects on either spending or revenues 
(Misiolek and Elder 1988). Still others find that diversification increases tax effort (Suyderhood 1994; Jordan and Wagner 2008; Chernick, Langley, and Reschovsky 2011), while some find that it reduces tax effort and burden (Pagano and Johnston 2000; Hendrick 2002). What the literature agrees on is that diversification leads to revenue or spending stability (Carroll 2009; Carroll and Stater 2009; Hendrick and Crawford 2014; Jordan, Yan, and Hooshmand 2017).

Only three studies examine - directly or indirectly - the relationship between the revenue structure and government fiscal health. Carroll's (2005) descriptive analysis indicates that states with diversified revenues have higher projected surpluses. Hendrick (2006) focuses on Chicago suburbs and finds that diversification increases the general fund balance. Focusing on three states, Gorina, Maher, and Joffee (2017) develop a qualitative or indicator variable that classifies local governments as fiscally distressed or not, and find that property tax dependence is associated with a lower probability of distress.

Our study contributes to the literature in several ways. First, it is generally claimed that diversification influences government fiscal health. Much of the focus in the literature, however, has been on separate analysis of spending or revenues. Although both are important outcomes, they do not tell us much about fiscal health because the level or growth of either spending or revenues may simply reflect voters' preferences and not necessarily budget difficulties. Fiscal health is not about whether governments spend or tax more or less, but whether they can afford to pay for their spending with the revenues that they raise (Jimenez 2019). Other fiscal health measures used in some of the studies are also problematic. Qualitative fiscal health measures mask a great deal of variation in the fiscal condition of governments. Projected surpluses are estimates. In this study, we improve on past studies by developing different financial ratios using audited financial data to measure a critical dimension of fiscal health - budgetary solvency. 
Second, we go beyond the traditional general fund-based financial ratios - which have been used in the literature but are associated with several issues (see methodology section) - and include government-wide budgetary solvency measures. To our knowledge, this is the first study to examine the impact of diversification on government-wide measures, allowing us to assess whether total revenues are truly sufficient to cover the total costs of operating government.

Third, rather than focus on a few states or metropolitan area, our sample includes midsized and large cities from across 48 states, improving our ability to generalize the findings to similar-sized cities across different states. Fourth, we address the issue of endogeneity by using instrumental variable regression. Endogeneity is typically caused by simultaneity and omitted variables. Studies often lag diversification measures to address simultaneity bias, but this approach does not correct for omitted variable bias. Our estimation strategy addresses both concerns. Fifth, we distinguish among the different ways that revenue structures can be broadened - including diversifying the tax and non-tax bases - and ensure that we cover different kinds of revenues that were excluded in previous studies.

Finally, our empirical findings point to the need to revise current theories of revenue diversification. Insights from public choice suggest that diversification creates a spending bias that ultimately leads to budgetary imbalance. In contrast, the organizational adaptation argument suggests that diversification helps government maintain its ability to pay for its obligations even in the face of unexpected external fiscal shocks. Both perspectives, however, focus on general revenue diversification, and do not recognize how types of diversification can produce distinct outcomes. Specifically, our results indicate that tax diversification leads to poor outcomes, whereas non-tax diversification improves budgetary solvency. We propose three causal mechanisms or pathways through which the types of diversification produce differential effects. 


\section{CURRENT THEORIES LINKING DIVERSIFICATION TO BUDGET OUTCOMES}

\section{Public Choice Perspective: Diversification and Fiscal Illusion}

Much of the revenue diversification literature is informed by the highly debated behavioral assumption in public choice theory that public officials - whether elected or appointed - are mainly motivated by self-interest (Buchanan 1967). Bureaucrats, for example, are described as desiring higher salaries and more non-monetary benefits, which they can get by requesting budgets that are higher than what the median voter demands (Niskanen 1972). Politicians, in contrast, are argued to be interested in being reelected (Downs 1956), leading them to support higher spending for particularistic goods to attract different groups of voters.

Public officials can succeed in expanding the size of government through fiscal illusion. Fiscal illusion refers to taxpayers' systematic misperception of the true cost of government, specifically, that the tax price of public services is lower than what it actually is (Buchanan 1967; Brennan and Buchannan 1980). Fiscal illusion arises from a number of factors including reliance on intergovernmental transfers, use of debt, and a greater number of renters than ownertaxpayers (Dollery and Worthington 1996; Afonso 2014). Revenue diversification is an additional cause of fiscal illusion (Dollery and Worthington 1996). Diversification leads to fiscal illusion through a number of mechanisms. For one, diversification creates complex tax structures (Buchanan 1967). Complex revenue systems make it harder for citizens to monitor changes in tax policies, which contributes to the difficulty of assessing the true tax cost of operating government (Wagner 1976). For another, diversification can lead to reliance on less visible taxes. The smaller the tax, the less visible it is, increasing the possibility that citizens will ignore, or be unaware of, any increase (Misiolek and Elder 1988; Jimenez 2015). Finally, diversification 
may lead to dependence on income-elastic taxes (Afonso 2013a, 2017). ${ }^{1}$ Revenues from such sources automatically rise when the economy grows and without increasing rates. Citizens may believe that revenue increases are not costing them much, making it easier for government officials to support higher spending (Buchanan 1967; Oates 1972). Not surprisingly, the hypothesis derived from fiscal illusion is that revenue diversification primarily affects government revenues and expenditures (Suyderhood 1994; Jordan and Wagner 2008; Chernick, Langley, and Reschovsky 2011; Hendrick and Degnan 2020).

We argue that fiscal illusion, extended to its logical conclusion, ultimately affects budgetary solvency. Because diversification can potentially lead to higher revenues and spending, it should not weaken budgetary solvency assuming that both revenue and spending increase at the same rate. This expectation, however, is unrealistic. Even with fiscal illusions in place, revenues cannot grow in perpetuity because of political, legal, and economic constraints. The well-documented, highly political, local tax revolts in the country have culminated in the enactment by voters of fiscal rules such as tax and expenditure limits (TELs) that have constrained the tax revenues of city governments but have had mixed, if not limited effects, on spending levels (see studies reviewed in Jimenez 2018). This development has forced some cities to engage in deficit spending (Jimenez 2017, 2018). In addition to political and legal pressures, revenue collections are not impervious to developments in the economy. Revenues are procyclical - declining during downturns. Government spending is countercyclical - increasing during recessions as unemployed workers rely more on government services (Holcombe and Sobel 1997). If revenues are not sufficient to meet spending pressures, the result is budgetary

\footnotetext{
${ }^{1}$ Note that revenue complexity and elasticity are two distinct causes of illusion (Dollery and Worthington 1996). Government can rely more on elastic sources without necessarily making the revenue structure more complex.
} 
imbalance. Some argue that the imbalance in the current period is financed through the issuance of debt, making it harder to balance budgets in succeeding fiscal years (Velasco 2000). Organizational Adaptation Perspective: Diversification and Modern Portfolio Theory

A different perspective suggests that diversification is a form of organizational adaptation intended to improve budget outcomes. The organizational approach argues that diversification is a means to improve the flexibility of government in dealing with fiscal shocks and maintaining their fiscal health (Hendrick 2002, 2011). City governments, in general, have limited ability to change external environmental factors, such as national economic or social trends, that affect their fiscal health (Ladd and Yinger 1989). City officials, thus, focus on modifying their government's internal fiscal structure to manage their fiscal health. The internal fiscal structure is a product of past and present fiscal and financial management decisions (Hendrick 2011).

Revenue diversification, in this light, is an attempt by city officials to adapt the internal fiscal structure to potential or existing external threats to government fiscal health (Shanon 1987; Misiolek and Elder 1988; Suyderhoud 1994; Carroll 2005, 2009; Hendrick 2002). Specifically, diversification is a strategy to reduce the risk of catastrophic revenue shortfalls caused by external economic or political events. Rather than a means to trick citizens to support a bloated government, as fiscal illusion suggests, revenue diversification is a "flexible financial management tool" (Henrick 2002, 52). This argument is based on Markowitz's (1952) modern portfolio theory, which argues that investing in firms in a high-growth sector will bring in bigger returns, but a decline in that sector can also lead to considerable losses. The stability of expected returns requires investing in stocks with the least covariance, which in turn necessitates diversifying investments across different industries. 
In the same way that a diversified investment portfolio promotes the stability of returns, a diversified revenue base reduces fluctuations in revenue flows if different sources are not highly correlated (White 1983; Misiolek and Elder 1988; Suyderhoud 1994). For example, income and sales taxes, as well as some charges and fees, correlate highly because they are income elastic. An economic downturn will reduce revenues from these sources. In contrast, the property tax is more stable across the business cycle. But overdependence on property taxes is also risky because of the proliferation of TELs that mainly target this source (Jimenez 2017). By relying on multiple revenue sources, cities are protected from economic or political developments that can lead to a significant reduction in collections from one revenue source (Hendrick 2002, 2011).

Under fiscal illusion, both the levels of revenues and expenditures are projected to increase with more diversification, but as we argued previously, expenditures are likely to be higher than revenues. In contrast, the organizational adaptation perspective does not necessarily focus on the level of revenues or expenditures. What it suggests is that diversification reduces the volatility specifically of revenue flows, which is consistent with the findings in the literature (Carroll 2009; Carroll and Stater 2009; Hendrick and Crawford 2014; Jordan, Yan, and Hooshmand 2017). More volatile revenue flows show large deviations from predicted trends, often displaying a sharp peak-trough pattern.

There is of course a tradeoff between revenue stability and growth. When cities diversify their revenue sources, they do not fully benefit from potential increases in the yield of more elastic sources. That is, cities do not fully capture increases in collections from income or sales tax, as well as some fees and charges, when the economy grows, if they only partially rely on these sources. Nonetheless, if the motivation is to preserve the ability of government to raise revenues to pay for the costs of services and to meet its other financial obligations, then revenue 
stability, rather than growth, is likely to be more important. In other words, a government with more stable revenues is in a better position to meet its expenditure commitments compared with a government that is exposed to a higher risk of rapid revenue decline (Hendrick 2002, 2011). An additional possible effect of diversification, as Hendrick and Crawford's (2014) research shows, is to reduce expenditure volatility for some governments. They argue that the revenue stability caused by diversification forces cities to also stabilize spending. It is more difficult to rapidly ramp up spending when revenues are predictable within and across fiscal years. In contrast, under conditions of greater volatility, unexpected revenue bumps generate additional funds that can be used to increase expenditures. Thus, stronger budgetary solvency is expected if diversification is being used as a managerial tool to promote stability in revenues as well as in spending, as suggested in the organizational adaptation perspective.

\section{RESEARCH METHODOLOGY}

To test the competing propositions, we collected data on cities with a population of 50,000 or more based on the results of the 2007 Census of Governments, which listed 674 cities that met the population threshold. This allowed us to have a consistent sample of cities across the years covered in the analysis. Our data are from 2006-2012, ensuring that we are not merely observing seasonal or one-off budget issues, but longer-term trends. Using the initial list of cities, we collected data from several sources, such as the Census of Governments, Annual Survey of State and Local Government Finances, and Comprehensive Annual Financial Reports (hereafter referred to as audited reports), among others. Our panel is unbalanced because of missing data for some cities (specifically, see the discussion of diversification measures).

\section{Measuring Budgetary Solvency ${ }^{2}$}

\footnotetext{
${ }^{2}$ Portions of this section draw heavily from Jimenez $(2018,209,2020)$
} 
To measure budgetary solvency, we use data from audited reports collected from cities, which are then manually encoded. These reports are prepared according to Generally Accepted Accounting Principles (GAAP). We focus on two dimensions of budgetary solvency identified by Johnson, Kioko, and Hildreth (2012): Operating position is the "net difference between revenues and expenses resulting from annual operations" (84), whereas financial position indicates "the government's ability to continue providing its basic services and fulfilling its financial commitments from current year revenues and prior year savings" (86). We further distinguish between general fund-based and government-wide solvency measures.

The general fund represents the operating budget of city governments and "accounts for the most basic, tax-supported activities of a local government" (Mead 2011, 172). We use data from governmental fund statements in audited reports, which are prepared using the current financial resources measurement focus. They report inflows, outflows, and balances of spendable financial resources in the current fiscal year (GASB 1999). The statements also use modified accrual accounting, which records financial resource flows in the fiscal year that they occur and up to 60 days after (Finkler 2011). To measure the operating position, we use the operating ratio, which is general fund revenues (or taxes, user fees, and grants in the current period) divided by general fund expenditures (or payments of cash or promise to pay for goods or services that are received in the current period). A ratio greater than 1 indicates a surplus, and a deficit if less. To measure financial position, we focus on unreserved and undesignated fund balance, which represents current financial resources that are in spendable form and can be used for any purpose (Mead 2011), and often serves as a rainy-day fund for city governments. We also divide unreserved fund balance by general fund expenditures to ensure comparability across cities. A 
low to negative ratio indicates that a city has declining, or already insufficient, financial resources to close unexpected deficits in the current budget period (Hendrick 2002, 2011). Although general fund-based measures are considered conventional measures of budgetary solvency, they have serious limitations. First, cities maintain other funds - such as enterprise and capital funds - and can transfer financial resources from these other funds to balance the general fund (Jimenez 2020). Second, cities do not necessarily include the same set of services in the general fund, which raises the question of whether the fund represents the totality of the operating budget (Mead 2011). Finally, because they focus on the flow of financial resources in the current period, general fund measures do not recognize questionable practices that defer costs to future years to close current deficits, such as underfunding of retirement benefits or issuance of non-capital debt or debt used to meet operational costs (GASB 1999).

In light of these issues, we also employ government-wide budgetary solvency measures using information from government-wide statements. These statements provide information for the government as a whole (not just distinct funds), covering all governmental activities financed by taxes and grants, as well as business activities supported by fees. Because we are measuring the budgetary solvency of the government as a whole, interfund transfers and inconsistent service grouping are nonissues. The statements use the economic resources measurement focus, providing information on all economic resources of a government, both financial and capital (GASB 1999). They are prepared using full accrual accounting, which records a revenue when it is earned whether cash is collected or not. All costs incurred in the current period are reported in that period regardless of the timing of the resource outflow (Finkler 2011). For example, total labor costs in the current period include not only salaries but also a portion of retirement benefits (e.g. pensions) already earned by employees. Even if the benefits are to be paid out in the future, 
government is obligated to set aside funding for them in the current period when the employee provided a service and earned a portion of the benefits as part of her total compensation. If a city does not meet its required annual benefit plan contributions, the underfunding is reported as a liability for the current budget period (see Mead 2011; GASB 1999).

To measure operating position, we use government-wide operating ratio, which is total revenues divided by total expenses (Jimenez 2018, 2020). Revenues include taxes, service fees, and operating grants and contributions from other governments (local, state and federal) and other organizations. The denominator is expenses, which are different from expenditures, and measure costs incurred in the fiscal year whether cash changed hands or not (Mead 2011). A ratio less than 1 indicates a government-wide operating deficit, and a surplus if greater than 1 .

To measure government-wide financial position, we use unrestricted net position. Unrestricted net position, similar to the general fund balance, can be used for whatever purpose and functions as a reserve (Johnson, Kioko and Hildreth 2012). However, unrestricted net position covers a more comprehensive set of liquid resources compared with fund balance. Whereas the latter only includes financial resources in spendable form such as cash, the former includes both spendable financial resources and other economic resources that are not in readily spendable form such as investments and inventory (as long as these are not restricted by law for use for a specific purpose) (Mead 2011). Although cash is the most liquid, investments and inventory are still considered liquid because they can be sold to produce cash in the current period (Finkler 2011). Unrestricted net position is also divided by total expenses.

\section{Measuring Revenue Diversification}

Following the convention in the literature, we measure revenue diversification using the Hirschman-Herfindahl Index or HHI. The formula used here is: 


$$
\mathrm{HHI}=\frac{1-\sum_{i}^{n} R^{2}}{1-\frac{100 \%}{n}}
$$

where $R$ is the ratio of each revenue category to total revenue for city $i$, and $n$ is the number of categories. The HHI ranges from 0 to 1 with higher values indicating greater diversification. An important question is, what types and categories of revenues should be included in measuring diversification? Suyderhoud (1994) shows that the diversification ranking of governments changes depending on which revenue sources are used and how they are categorized.

We use measures developed for municipal governments, in particular, Carroll's (2009) indices, which are similar to others (e.g. Hendrick 2002; Jordan and Wagner 2008; Hendrick and Crawford 2014; Carroll, Eger, and Marlowe 2003). An advantage of her approach over other measures is that it distinguishes between tax and non-tax diversification. As Carroll $(2009,36-$ 37) argues, the tax HHI “appropriately captures diversification when non-tax revenue sources are unavailable (or available on a very limited basis) and diversification is more likely to occur within the tax structure" ...whereas the non-tax HHI "most appropriately captures diversification when local options for sales and income taxes are unavailable (or strictly limited) but non-tax revenue sources like user charges and fees are more accessible and likely to garner greater diversification." Carroll uses property, sales and gross receipts, income, and other taxes to calculate the tax HHI; and total taxes, current charges, and miscellaneous general revenue to calculate the non-tax HHI. ${ }^{3}$

We introduce an additional HHI-based measure that expands on the categories used in Carroll's non-tax HHI. Some argue that utility revenues should be taken into account when measuring diversification (Hendrick 2002). Utility revenues include earnings of publicly owned

\footnotetext{
${ }^{3}$ Current charges exclude utilities and apply to general public services (e.g. sewerage, airports, hospitals), whereas miscellaneous general revenue includes revenues other than those classified as taxes, intergovernmental revenue, current charges, or utility revenues (e.g. special assessments) (U.S. Bureau of Census 2006).
} 
and controlled utilities from the sale of commodities or services such as electricity, water, gas, and transit (U.S. Bureau of Census 2006). Based on the 2012 Census of Governments, utility revenues comprise more than 15 percent of own-source revenues for cities with a population of 50,000 or more. The expanded non-tax HHI covers total taxes, current charges, miscellaneous general revenue, and utility revenue. Going forward, we refer to Carroll's non-tax diversification measure as "non-tax HHI" to distinguish it from the "expanded non-tax HHI."

Data from audited reports cannot be used to calculate the HHIs because reports from different cities do not consistently disaggregate revenues by type. Instead, we use data from the Census of Governments, which collects financial information on all governments in the U.S. every five years. During off-census years, the U.S. Census Bureau conducts the Annual Survey of State and Local Government Finances to collect data from a small sample of cities. Because this survey does not cover all cities, some cities in our sample have missing data in off-census years. The average number of cities per year with complete data is 568 and covering 48 states. $^{4}$

\section{Control Variables}

We include several control variables in our models. Because cities rely significantly on own source revenues to finance the provision of local services, the health of the local economy is one of the most important factors that determine city fiscal condition. Private sector employment is a general measure of city economic health (Ladd and Yinger 1989). We also include unemployment rate. The contraction in wages and salaries affects not only income tax collections of cities that levy such a tax, but also reduces sales tax revenues as consumption declines (Alm, Buschman, and Sjoquist 2011). High unemployment also increases city spending as the

\footnotetext{
${ }^{4}$ Vermont and New Jersey are excluded. No Vermont city meets the study's population threshold. New Jersey municipalities' financial reports are not GAAP-consistent.
} 
unemployed rely more on city-provided services. We control for housing prices given the importance of the property tax for most cities (Jimenez 2013, 2020). ${ }^{5}$

Socio-demographic and political factors also influence city budgetary solvency. Median household income proxies for the local revenue base. Population size and change have unclear effects. A bigger or growing population indicate greater demand for city services, leading to higher expenditures. Still, it is possible that larger and growing cities have stronger economies that allow them to generate more revenues to cover their expenses (Jimenez 2013, 2020).

For political factors, the models control for citizens' policy preferences, as well as ethnic fragmentation. We measure citizens' policy preference using Tausanovitch and Warshaw's (2014) policy conservatism index, which measures citizens' policy taste along a liberalconservative continuum. Conservative policy ideology is associated with lower spending, taxes, and debt (Tausanovitch and Warshaw 2014). Alesina, Baqir, and Easterly (1999) also show that ethnic fragmentation can lead to deficits as intense competition among ethnic or racial groups drives up spending for particularistic goods and reduces the willingness to pay taxes.

Finally, the models control for intergovernmental and local governance factors. Cities receive grants from the federal and state governments to deliver services. The models include intergovernmental revenue as a percentage of city own-source revenues. Cities also have different service responsibilities, which we measure using Clark and Ferguson's (1983) functional performance index. ${ }^{6}$ Lastly, we control for government form based on the finding that the mayor-council form is associated with government-wide budgetary imbalance (Jimenez 2020). Table 1 provides additional details on the variables. We use natural log transformations

\footnotetext{
${ }^{5}$ We use one-year lag of the housing price index because of the delay before changes in market values are reflected in assessed property values.

${ }^{6}$ We use one-year lags of grant dependence and the functional responsibility index to address possible simultaneity.
} 
for control variables with skewed distributions. ${ }^{7}$ Also, we convert non-ratio fiscal and income measures to year 2000 dollars to adjust for inflation using the implicit price deflator from the U.S. Bureau of Economic Analysis.

(Table 1 here)

\section{Estimation Approach}

The primary estimation issue we face is endogeneity, which can be caused by simultaneous causation and omitted variables, among others. In the case of simultaneity, officials can change revenue policies in response to developments in their city's budgetary solvency. We address simultaneity by lagging the diversification measures. Omitted variables is a more serious concern. First, unmeasured, time-invariant, state-specific factors - such as state laws - can affect both city revenue structure and budgetary solvency. ${ }^{8}$ We use least squares dummy variable (LSDV) regression to address the issue, which involves including state dummies in the models to control for the unmeasured, time-invariant, state-specific factors. We also include year dummies to control for national events that can affect all cities such as economic recessions.

Second, an unmeasured time-variant variable at the city level - the changing fiscal preferences of city residents, for example - could be driving policies that affect both the degree of diversification and budgetary solvency. Budgetary solvency is dependent on both revenues and spending. If residents prefer higher spending and are willing to pay for services, budgetary solvency can be maintained. To raise additional revenues, citizens might prefer to rely on several revenue sources. If citizens' fiscal tastes determine both revenue structure and budgetary solvency, any observed relationship between the two variables is spurious because it reflects the

\footnotetext{
${ }^{7}$ Because the log of zero and negative values is undefined, we add a constant number to ensure values can be logtransformed and observations are not dropped.

${ }^{8}$ For example, state-imposed laws such as local TELs can force cities to rely on non-tax sources (Jimenez 2017), but also have a direct effect on city operating and financial positions (Jimenez 2018).
} 
common correlation of both variables with the unmeasured citizen fiscal taste. Although the models already include Tausanovitch and Warshaw's (2014) policy conservatism index, this index uses data from national rather than city-level citizen surveys, and may not fully measure municipal-level citizen fiscal taste. We use Instrumental Variable (IV) regression to address omitted variable bias at the city level. Our identification strategy involves using two instruments. Valid instruments are directly correlated with the endogenous regressor (diversification measures) but only indirectly correlated (via the endogenous regressor) with the outcome variable (solvency measures) (Wooldridge 2002). The validity of instruments is often highly contested. We follow the typical process for establishing the appropriateness of our identification strategy, which involves developing a plausible theory for why we believe our instruments are sound, and empirically testing for their validity.

The first instrument is the diversification measures in $1972 .{ }^{9}$ Cities have slowly tapped other revenue sources (e.g. fees) across decades while maintaining traditional sources (e.g. property taxes). By building on their revenue mix rather than radically altering it, a city's past revenue structure should still significantly correlate with its current structure. Also, given the lag of 35 to 40 years, revenue policies in the early 1970s can only indirectly affect - via the current revenue structure that they helped shape - budget developments from 2006 onward.

The second instrument is an index of state legal provisions on local initiatives - adapted from Matsusaka (2004) and used by Jimenez (2018) - that measures whether state law does not allow all cities within a state to have the initiative, allows only some cities, and allows all cities. Voters have used initiatives to enact TELs (Brooks and Phillips 2007) that have limited governments' ability to increase taxes and forced them to rely on non-tax revenue sources

\footnotetext{
${ }^{9}$ This is the earliest year for which complete data are publicly available.
} 
(Jimenez 2017, 2018; Matsusaka 2004). It is expected that in states that allow local initiatives, city tax revenue choices are more constrained, forcing them to rely more on non-tax revenues. The index is also unlikely to be directly correlated with city budgetary solvency because state laws on local initiatives do not contain any provisions that directly affect city fiscal policies. We empirically examine the validity of the instruments by relying on the results of the IV regression including the signs and statistical significance of the instruments' coefficients, the F-test for instrument joint significance, and the Hansen-J statistic (see Baum, Schaffer, and Stillman 2010).

\section{EMPIRICAL RESULTS}

\section{Results of LSDV Regression Models}

Table 2 contains the results of the LSDV models. We use Newey-West HAC (heteroskedasticity- and autocorrelation-consistent) standard errors. Each panel includes only a single diversification measure because of collinearity. Because of space consideration, we do not discuss the results for the control variables. Panels 1-6 show the results for the general fundbased solvency measures. None of the HHIs shows a statistically significant effect. This could be a reflection of the limitations of the general fund measures that we previously discussed.

(Table 2 here)

Panels 7-12 focus on government-wide measures. Panels 7-9 show that the effects of the tax and non-tax HHIs on the operating ratio are distinct. The tax HHI has a negative and moderately statistically significant $(\mathrm{p}<0.05)$ relationship with the operating ratio. While the non-tax $\mathrm{HHI}$ is not statistically significant, the expanded non-tax $\mathrm{HHI}$ has a positive and moderately significant relationship $(\mathrm{p}<0.05)$ with the operating ratio. Looking at panels $10-12$, all three diversification measures are highly correlated with unrestricted net position ratio. The pattern of results indicating a differential effect of tax and non-tax diversification persists. An 
increase in the tax HHI reduces net position $(\mathrm{p}<0.01)$, but an increase in the non-tax HHI or the expanded non-tax HHI raises the unrestricted net position ratio (at $\mathrm{p}<0.001$, respectively).

Figure 1 shows the predicted effects of the diversification measures. We track the predicted values of a specific budgetary solvency measure at different points of an HHI. The predicted values are based on the LSDV models where the diversification measures are statistically significant. We compare the predicted values of a budgetary solvency measure when a specific $\mathrm{HHI}$ is set to 0 ("non-diversified city" that relies on a single revenue source among those included in a specific HHI) and 1 ("diversified city" that relies equally on all sources included in a specific $\mathrm{HHI}$ ) to paint a better picture of the magnitude of the effect of complete diversification. Focusing on the tax HHI and government-wide operating ratio, the nondiversified city's operating ratio is 1.029 , or a surplus, compared with 0.995 for the diversified city, or a deficit. The pattern is reversed for expanded non-tax diversification. The diversified city enjoys a surplus (ratio of 1.020) compared with a deficit for the non-diversified city (0.975).

(Figure 1 here)

Looking at the tax HHI and government-wide unrestricted net position ratio, the nondiversified city's predicted ratio is 0.452 , which means that its unrestricted total reserves can cover 45.2 percent of total expenses in a given fiscal year. In contrast, the unrestricted net position of the diversified city only covers 25.2 percent of expenses, or 20 points lower than that of the non-diversified city. For the non-tax HHI, the non-diversified city's total reserves are equivalent to 10.6 percent of expenses, compared with 41.2 percent for the diversified city, or a difference of 30.6 points. For the expanded non-tax HHI, complete diversification leads to an even larger difference in unrestricted net position at approximately 42.4 (Although note that the results are no longer significant at the 95 percent level at the very low end of the HHI). 


\section{Results of IV Regression Models}

Table 3 contains the results of the IV regression. We do not present and discuss the full results because of space consideration, and we focus instead on the results for the instruments in stage one, and for the diversification measures in stage two. One of our instruments (initiative index) is measured at the state level and is perfectly collinear with state dummies. As an alternative, we use region dummies. The sign and statistical significance of the coefficients for the instruments validate our theory of why we believe the instruments are directly correlated with the endogenous variable. Specifically, as expected, deep lags of the diversification measures are statistically significant and positively correlate with current diversification. The initiative index is also significantly correlated with revenue diversification, and the signs are in the expected direction. The index is negatively associated with tax diversification but has a positive relationship with non-tax diversification. This means that cities in states that allow local initiatives have difficulty accessing tax sources as revealed by a less diversified tax structure, forcing them to expand to non-tax sources as indicated by a more diversified non-tax structure. The F-test for the two instruments are 9 to 26 times higher than the prescribed threshold of 10 (Staiger and Stock 1997), indicating that the instruments, jointly, strongly predict both types of diversification. For all panels, the Hansen-J statistic is statistically insignificant, which means that the instruments are not directly correlated with the main outcome variables or the solvency measures. These results show that the instruments meet the two conditions for validity.

(Table 3)

The results of the IV regression confirm most of the findings from the LSDV models. However, it is important to keep in mind that the results of the LSDV and IV models are not directly comparable because the latter includes region rather than state dummies. Looking at 
panels 13-18, none of the HHIs is correlated with any general fund-based measures. In panels

19-24, the tax HHI no longer has a significant relationship with the government-wide operating ratio, but the expanded non-tax HHI continues to have a positive and moderately statistically significant effect $(\mathrm{p}<0.05)$. The results for government-wide reserves are unchanged. Whereas tax diversification reduces unrestricted net position, non-tax diversification produces the opposite effect. These relationships remain highly statistically significant $(\mathrm{p}<0.001){ }^{10}$

\section{DISCUSSION AND CONCLUSION}

The empirical results indicate that there is a need to revise current thinking about the effects of revenue diversification. Specifically, the literature does not explore how different types of diversification can lead to dissimilar outcomes. Whether using the lens of public choice/fiscal illusion or the organizational adaptation/modern portfolio theory, diversification is treated as a generic concept, rather than a multidimensional phenomenon that can be measured in different ways. We have not been successful in finding any published study - whether theoretical or empirical - that explicitly argues that the distinct types of diversification we measure here are associated with divergent budget outcomes. In this study, we find evidence that the type of diversification matters. On the one hand, the results for tax diversification provide support for the fiscal illusion argument. The LSDV results indicate that tax diversification is associated with government-wide operating deficits and smaller unrestricted net position, indicating that governments are spending more than the revenues they raise, and are raiding their reserves. The IV regression results confirm the effects of tax diversification on unrestricted net position. On the other hand, the results of both the LSDV and IV regression models indicate that increasing

\footnotetext{
${ }^{10}$ Beyond the results presented here, we experiment with additional controls and use three-year moving averages of the solvency variables to further ensure that we are not measuring short-term trends. These changes do not alter the main conclusions of the paper. We also run models using a measure of total revenue diversification (covering all revenue categories, both tax and non-tax), but the results are not significant.
} 
reliance on non-tax sources can be an effective risk-management strategy, as outlined in the organizational adaptation argument. Specifically, cities that have broadened their revenue structures by tapping non-tax sources have higher total operating ratios and bigger reserves.

For some, building up reserves is inefficient because, accordingly, these are used by officials for personal benefit such as higher salaries (Migue and Belanger 1973). However, the literature on financial management suggests that cities that save are better prepared to meet unexpected spending caused by natural catastrophes, or cash flow issues precipitated by a recession. When cities do not save for rainy days, the alternatives are disruptive budget cuts, unplanned tax increases, or costly borrowing (Hendrick 2002, 2006; Johnson, Kioko, and Hildreth 2012). It also must be emphasized that the unrestricted net position does not merely indicate whether a government has enough savings for rainy days. It is also considered a measure of inter-period equity or whether government is financing services that benefit today's taxpayers by using current revenues, rather than passing on the costs to future taxpayers (GASB 1999). A persistent decline in unrestricted net position not only indicates that revenues are becoming insufficient to cover present costs, but also that government is sustaining current operational spending by incurring debt (Mead 2011) or underfunding pension and other post-employment benefits (Johnson, Kioko, and Hildreth 2012). These are highly questionable practices that harm cities’ fiscal future (GASB 1999).

Why should the outcomes of tax and non-tax diversification be different? Although the theoretical literature does not provide explicit answers, we suggest three causal mechanisms to explain the contrasting findings. One explanation is that it is easier to increase non-tax instruments compared with general taxes. The cutback management literature suggests that local governments are most able and willing to increase non-tax revenue sources compared with taxes 
(see Afonso 2013b; Jimenez 2017). Fees and charges are not constrained by TELs and other state or local laws that mainly target taxes (Jimenez 2017, 2018). A criticism of this explanation, which is explored below, is that the expected yield from fee increases is not guaranteed.

The second explanation pertains to the elasticity of the revenue source. Two types of elasticities matter here - the income elasticity of the revenue source over the business cycle, and the price elasticity of demand for services. Income-elastic revenues are sensitive to fluctuations in private income over the business cycle. As previously mentioned, cities are vulnerable to revenue decline when they rely on income-elastic sources such as income and sales taxes (Holcombe and Sobel 1997). In contrast, property taxes are more stable across the economic cycle, ensuring a steadier flow of revenues (Alm, Buschman and Sjoquist 2011). The cities with the least diversified tax structures in the sample rely more heavily on property taxes.

Is the yield from non-tax sources such as charges and fees also stable across the economic cycle? Fisher's (2007) estimates suggest that demand for public services, to a certain degree, is responsive to changes in private income. If so, revenues from charges and fees will decline when private incomes contract during downturns. Governments can of course increase fees. The impact of the increase on revenue yield depends in part on the price elasticity of demand, which measures the sensitivity of consumption to price shifts. If demand is price inelastic, that is, consumption is not sensitive to the price increase, higher fees will generate additional revenues. If elastic, the expected yield from fee increases will not materialize as users simply reduce their consumption of a service. Unfortunately, the literature does not offer any definitive conclusions about the price elasticity of local public services. One reason for this is that there are several groups of services subject to charges and fees, with each group comprised of numerous service subtypes that have different price elasticities. Also, service groups may have 
different markets of users with distinct behavioral responses to price changes. For charges, the top three sources for municipalities according to the 2012 Census of Government are sewerage (29.7 percent of total charges), air transportation (14.6), and hospitals (9.3). Sewerage is price inelastic (Martin and Wilder 1992), but price responsiveness varies widely by subtype of airport and hospital services. ${ }^{11}$ The top three sources of utility revenues - electricity (46.8 percent of total utility revenues), water (36.5), and gas (8.4) - have been described as price inelastic, but others show that the estimated elasticities vary depending on the specific market of users, and whether the focus is on the short or long run. ${ }^{12}$

The third explanation is that the link between the revenue source and service influences the extent to which officials can hide the government costs, and limit or enhance their ability to maximize budgets. Current charges and utility fees are more closely linked to services provided compared with general taxes. Fees and charges approximate a market-like arrangement for financing public services: Government supplies a service that citizens demand in exchange for a fee. This arrangement can positively affect fiscal health in two ways. For one, it enhances economic efficiency by matching supply with demand. Governments supply services that citizens prefer as revealed through their willingness to pay for those services (Fischer 2007). Greater reliance on fees and charges improves budgetary solvency by limiting city officials' ability to increase spending on services that residents are not willing to pay for. Officials are less able to hide the cost of government through fiscal illusion because citizens can clearly see the link between service costs (what citizens pay) and service consumption (what they get). For

\footnotetext{
${ }^{11}$ Aeronautical (e.g. hangar) and airport commercial services (e.g. retail) have different elasticities. For hospital services, outpatient services are relatively inelastic, but not in-patient services (Ellis, Martins, and Zhu 2017).

${ }^{12}$ Residential use for utility services is relatively price inelastic, but not necessarily for commercial or industrial use. Elasticities also differ in the short run (less than a year) and long run (a year or more) (Dalhuisen et al. 2003; Burke and Yang 2016; Burke and Abayasekara 2018). In the short run, demand is price inelastic as consumers cannot quickly change their consumption behavior. In the long run, demand is relatively elastic as consumers have more time to adjust to the higher charge (e.g. consumers install solar panels to reduce electricity bills).
} 
another, not only does market-based service provision limit the scope of services, it also forces government to exercise greater fiscal discipline for services that it already provides. Fee-based services are generally self-supporting. Sjoquist and Stoycheva (2012) show that revenues from the biggest utilities (electricity, water, and gas), and the top three sources of current charges (sewerage, air transportation, and hospitals) support spending for such services. This improves fiscal discipline by forcing government to spend only what it earns from fees and charges.

In contrast to charges and fees, there is a weaker link between general taxes and services. General taxes (property, income and sales taxes) represent a common fiscal pool that can be used to finance any service. For general tax-supported services, there is less incentive to enhance efficiency because funding is decided through the more political budgeting process (Weingast, Shepsle, and Johnsen 1981). In this budgeting process, the choice to fund programs is not strictly made on the basis of whether residents are willing to pay for the service, or whether the service can generate sufficient revenues to support its own operations, but on whether the service is supported by officials and voters. The absence of market discipline leaves room for potentially wasteful spending (Niskanen 1972; Sjoquist and Stoycheva 2012). This expectation is consistent with the fiscal illusion literature (previously cited) focusing exclusively on tax diversification, and which finds that general tax-supported services are often provided at too high a level.

Note that the three causal mechanisms are not mutually exclusive. Although each focuses on adjustments on either the revenue or spending side of budgetary solvency, the combined effect of these changes is to improve fiscal health. If cities can easily increase charges and fees (relative to general taxes) and the demand for major fee-based services is price inelastic, additional revenues can be generated. If fees improve economic efficiency, spending can be controlled. The net effect of higher revenues and lower spending is stronger budgetary solvency. 
The critical point highlighted by our findings and the causal mechanisms that we propose is that diversification is neither irredeemably bad nor unquestionably good for fiscal health, as extant theories suggest. Contrary to the public choice/fiscal illusion perspective, diversification does not always enable officials to maximize budgets, thereby precipitating budgetary imbalance. Compared with general taxes, diversifying to fees can potentially enhance fiscal discipline and health. Contrary to the organizational adaptation/modern portfolio perspective, diversification does not always help governments to prepare for fiscal shocks. In particular, diversifying from the stable property tax to more elastic tax sources can lead to poor outcomes. ${ }^{13}$

The empirical examination of the causal mechanisms is beyond the scope of this study, but we have laid out the critical first step in clarifying and further developing a more nuanced theory of revenue diversification. We believe that further investigation of the explanations we offer will be an important and valuable extension to this work. Other limitations of the study should be noted. Our primary measures of fiscal health - operating ratios and net position - can tell us whether government is living within its means and is not engaging in questionable financial management practices that mortgage its fiscal future. However, these measures cannot tell us whether the government is delivering both the quantity and quality of services that residents prefer. In addition, government's revenue choices also have distinct efficiency and equity effects. The need to examine how revenue diversification shapes these different outcomes, we hope, will inspire more research in this field.

\section{References \\ Afonso, Whitney. 2013a. "Diversification Toward Stability? The Effect of Local Sales Taxes on Own Source Revenue.” Journal of Public Budgeting, Accounting \& Financial Management. 25(4): 649-674.}

\footnotetext{
${ }^{13}$ The effect of property tax reliance is not explained solely by its stability. The "alternative view" of property tax is that it is a benefits tax. As Fischer $(2007,361)$ describes, "The property tax is the 'price' for consuming local services, with all consumers paying the costs that their consumption imposes on the government." If this is the case, then property tax reliance can also affect fiscal health via the efficiency mechanism, similar to charges and fees.
} 
Afonso, Whitney. 2013b. "Coping with the Great Recession: Theory and Practice for County Governments." International Journal of Public Administration. 36(11): 768-779.

Afonso, Whitney. 2014. "Fiscal Illusion in State and Local Finances: A Hindrance to Transparency." State and Local Government Review. 46(3): 219-228.

Afonso, Whitney B. 2017. "Revenue Portfolio and Expenditures: An Examination of the Volatility of Tax Revenue and Expenditure Patterns During the Great Recession. International Journal of Public Administration. 40(10): 896-905.

Alesina, Alberto, Reza Baqir, and William Easterly. 1999. "Public Goods and Ethnic Divisions." Quarterly Journal of Economics. 114(4): 1243-1284.

Alm, James, Robert Buschman, and David Sjoquist. 2011. "Rethinking Local Government Reliance on the Property Tax." Regional Science and Urban Economics. 41: 320-331

Baum, Christopher, Mark Schaffer, and Steven Stillman. 2010. Ivreg2: Stata Module for Extended Instrumental Variables/2SLS, GMM and AC/HAC, LIML and K-Class Regression. http://ideas.repec.org/c/boc/bocode/s425401.html (accessed on 7-1-2019)

Brennan, Geoffrey, and James Buchanan. 1980. The Power to Tax: Analytical Foundations of a Fiscal Constitution. Cambridge: Cambridge University Press.

Brooks, Leah and Justin Phillips. 2007. "An Institutional Explanation for the Stickiness of Federal Grants." Journal of Law, Economics, and Organization 26: 243-64.

Buchanan, James. 1967. Public Finance in Democratic Process: Fiscal Institutions and Individual Choice. Chapel Hill: University of North Carolina Press.

Burke, Paul and Ashani Abayasekara. 2018. "The Price Elasticity of Electricity Demand in the United States: A Three-Dimensional Analysis.” Energy Journal 39(2): 123-146

Burke, Paul and Hewen Yang. 2016. "The Price and Income Elasticities of Natural Gas Demand: International Evidence.” Energy Economics 59: 466-474.

Carroll, Deborah. 2005. "Are State Governments Prepared for Fiscal Crises? A Look at Revenue Diversification During the 1990s." Public Finance Review 33, no. 5: 575-602.

Carroll, Deborah. 2009. "Diversifying Municipal Government Revenue Structures: Fiscal Illusion or Instability? Public Budgeting \& Finance 29, no. 1: 27-48.

Carroll, Deborah and Keely Jones Stater. 2009. "Revenue Diversification in Nonprofit Organizations: Does It Lead to Financial Stability?" Journal of Public Administration Research and Theory 19, no. 4: 947-956.

Carroll, Deborah, Robert J. Eger and Justin Marlowe. 2003. "Managing Local Intergovernmental Revenues: The Imperative of Diversification.” International Journal of Public Administration 26, no. 13: 1495-1519.

Chernick, Howard, Adam Langley, and Andrew Reschovsky. 2011. "Revenue Diversification and the Financing of Large American Central Cities." Lincoln Institute of Land Policy.

Clark, Terry and Lorna Ferguson. 1983. City Money: Political Processes, Fiscal Strain and Retrenchment. New York: Columbia University Press.

Dalhuisen, Jasper, Raymond Florax, Henri de Groot, and Peter Nijkamp. 2003. "Price and Income Elasticities of Residential Water Demand: A Meta-Analysis." Land Economics 79: 292-308.

Dollery, Brian and Andrew Worthington. 1996. "The Empirical Analysis of Fiscal Illusion." Journal of Economic Surveys 10:261-97.

Ellis Randall, Bruno Martins, Wenjia Zhu. 2017. "Health Care Demand Elasticities by Type of Service.” Journal of Health Economics. 55: 232-243. 
Finkler, Steven. 2011. Financial Management for Public, Health and Not-For-Profit Organization. 3rd ed. Upper Saale River, NJ: Prentice Hall.

Fisher, Ronald. 2007. State and Local Public Finance $4^{\text {th }}$ Edition. Mason, OH: Thomson SouthWestern.

Gorina, Evgenia, Craig Maher, and Marc Joffe. 2018. "Local Fiscal Distress: Measurement and Prediction." Public Budgeting \& Finance 38(1): 72-94.

Governmental Accounting Standards Board (GASB). 1999. Statement No. 34 of the Governmental Accounting Standards Board: Basic Financial Statements-and Management's Discussion and Analysis-For State And Local Governments. Norwalk, CT: GASB.

Hendrick, Rebecca. 2002. "Revenue Diversification: Fiscal Illusion or Flexible Financial Management?" Public Budgeting and Finance 22, no. 4: 52-72.

Hendrick, Rebecca. 2006. "The Role of Slack in Government Finances." Public Budgeting and Finance 26(1): 14-46.

Hendrick, Rebecca. 2011. Managing the Fiscal Metropolis. Washington DC: Georgetown Press.

Hendrick, Rebecca, and Jared Crawford. 2014. "Municipal Fiscal Policy Space and Fiscal Structure: Tools for Managing Spending Volatility." Public Budgeting \& Finance 34, no. 3: 24-50.

Hendrick, Rebecca, and Robert P. Degnan. 2020. "In the Shadow of State Government: Changes in Municipal Spending After Two Recessions." American Review of Public Administration 50(2): 161-175.

Holcombe, Randall and Russell Sobel. 1997. Growth and Variability in State Tax Revenue: An Anatomy of State Fiscal Crises. Westport, CT: Greenwood.

Jimenez, Benedict S. 2013. "Strategic Planning and the Fiscal Performance of City Governments During the Great Recession." American Review of Public Administration 43: 581-601.

Jimenez, Benedict S. 2015. "The Fiscal Performance of Multi-Level Local Governments. Public Finance Review 43, no. 5: 606-635.

Jimenez, Benedict S. 2017. "Institutional Constraints, Rule Following and Circumvention: Tax and Expenditure Limits and the Choice of Fiscal Tools During a Budget Crisis." Public Budgeting and Finance 37(2): 5-34

Jimenez, Benedict S. 2018. "Fiscal Institutional Externalities: The Negative Effects of Tax and Expenditure Limits on Municipal Budgetary Solvency." Public Budgeting and Finance. 38(3): 3-31.

Jimenez, Benedict S. 2019. "Power to the People?: The Initiative Process and Fiscal Discipline in City Governments." Urban Affairs Review. 55(5): 1280-1311.

Jimenez, Benedict S. 2020. "Municipal Government Form and Budget Outcomes: Political Responsiveness, Bureaucratic Insulation, and the Budgetary Solvency of Cities." Journal of Public Administration Research and Theory 30(1): 161-177

Johnson, Craig, Sharon Kioko, and W. Bartley Hildreth. 2012. "Government-Wide Financial Statements and Credit Risk." Public Budgeting \& Finance 32, no. 1: 80-104

Jordan, Meagan and Gary Wagner. 2008. "Revenue Diversification in Arkansas Cities: The Budgetary and Tax Effort Impacts." Public Budgeting \& Finance 28, no. 3: 68-82.

Jordan, Meagan M., Wenli Yan, and Somayeh Hooshmand. 2017. "The Role of State Revenue Structure in the Occurrence and Magnitude of Negative Revenue Variance." American Review of Public Administration 47.4:469-478.

Ladd, Helen F. and John M. Yinger. 1989. America's Ailing Cities: Fiscal Health and the Design of Urban Policy. Baltimore, MD: John Hopkins University 
Matsusaka, John G. 2004. For the Many or the Few: The Initiative, Public Policy, and American Democracy. Chicago: University of Chicago Press.

Markowitz, Harry. 1952. "Portfolio selection.” Journal of Finance 7, no. 1:77-91.

Mead, Dean Michael. 2011. An Analyst's Guide to Government Financial Statements. Norwalk, CT: Governmental Accounting Standards Board.

Migue, Jean-Luc and Belanger, Gerard. 1974. "Towards a General Theory of Managerial Discretion." Public Choice 17, 24-43.

Misiolek, Walter, and Harold Elder. 1988. "Tax Structure and the Size of Government: An Empirical Analysis of the Fiscal Illusion and Fiscal Stress Arguments. Public Choice 57, no. 3: 233-245.

Niskanen, William. 1972. Bureaucracy and Representative Government. New York: Aldine. Oates, Wallace. 1972. Fiscal Federalism. New York: Harcourt Brace Jovanovich.

Pagano, Michael A., and Jocelyn M. Johnston. 2000. "Life at the Bottom of the Fiscal Food Chain: Examining City and County Revenue Decisions." Publius: The Journal of Federalism 30, no. 1: 159-170.

Shi, Yu, and Jie Tao. 2018. "“Faulty' Fiscal Illusion: Examining the Relationship Between Revenue Diversification and Tax Burden in Major US Cities Across the Economic Cycle." Local Government Studies 44, no. 3: 416-435.

Sjoquist, David and Rayna Stoycheva. 2012. "Local Revenue Diversification: User Charges, Sales Taxes, and Income Taxes." Oxford Handbook of State and Local Government Finance. Edited by R. Ebel and J. Petersen. UK: Oxford University Press.

Staiger, Douglas and James Stock. 1997. "Instrumental Variables Regression with Weak Instruments." Econometrica 65(3): 557-586

Suyderhoud, Jack. 1994. "State-Local Revenue Diversification, Balance, and Fiscal Performance." Public Finance Quarterly 22, no. 2: 168-195.

Tausanovitch, Chris, and Christopher Warshaw. 2014. "Representation in Municipal Government." American Political Science Review 108(3): 605-41

U.S. Bureau of the Census. 2006. Government Finance and Employment Classification Manual Covering the Activities of the Federal, State, and Local Governments. Washington DC: U.S. Bureau of the Census.

Velasco, Andrés. 2000. "Debts and Deficits with Fragmented Fiscal Policymaking." Journal of Public Economics 76(1): 105-125

Wagner, Richard. 1976. "Revenue Structure, Fiscal Illusion and Budgetary Choice." Public Choice 25: 45-61.

Wang, Xiaohu, Lynda Dennis, and Yuan Sen Tu. 2007. "Measuring Financial Condition: A Study of U.S. States." Public Budgeting \& Finance 27, no. 2: 1-21.

Weingast, Barry, Kenneth Shepsle, and Christopher Johnsen. 1981. "The Political Economy of Benefits and Costs: A Neoclassical Approach to Distributive Politics." Journal of Political Economy 89(4): 642-64.

White, Fred. 1983. "Trade-Off in Growth and Stability in State Taxes." National Tax Journal 36, no. 1: 103-114.

Wooldridge, Jeffrey M. 2002. Econometric Analysis of Cross Section and Panel Data 2nd ed. Cambridge: MIT Press 
TABLE 1

Variable Operationalization, Data Sources and Descriptive Statistics

\begin{tabular}{|c|c|c|c|c|c|}
\hline Variables & Data Source & Mean & Std. Dev. & Min & Max \\
\hline \multicolumn{6}{|l|}{ Outcome Variables } \\
\hline General fund operating ratio (See main text for definition) & Audited reports & 1.04 & 0.20 & 0.28 & 3.50 \\
\hline General fund unreserved undesignated balance ratio (See main text) & Audited reports & 0.20 & 0.20 & -0.98 & 2.12 \\
\hline Government-wide operating ratio (See main text) & Audited reports & 1.01 & 0.11 & 0.28 & 2.26 \\
\hline Government-wide unrestricted net position ratio (See main text) & Audited reports & 0.34 & 0.47 & -2.16 & 3.78 \\
\hline \multicolumn{6}{|l|}{ Main Independent Variables } \\
\hline Tax HHI (See main text for definition; 1-year lag) & CoG, ASSLGF & 0.57 & 0.23 & 0.00 & 0.97 \\
\hline Non-tax HHI (See main text; 1-year lag) & CoG, ASSLGF & 0.76 & 0.15 & 0.18 & 0.99 \\
\hline Expanded non-tax HHI (See main text; 1-year lag) & CoG, ASSLGF & 0.77 & 0.15 & 0.16 & 1.00 \\
\hline \multicolumn{6}{|l|}{ Controls } \\
\hline Housing price index (Measures the movement of single-family house prices; 1 -year lag) & FHFA & 200.86 & 52.25 & 103.73 & 345.34 \\
\hline$\%$ change in housing price index (Annual $\%$ change; 1 -year lag) & FHFA & -0.59 & 9.31 & -34.36 & 33.33 \\
\hline Private sector employment (Private sector employees as \% of total population) & ACS & 45.51 & 5.38 & 16.99 & 62.01 \\
\hline Unemployment rate (Unemployed as \% of total workforce) & ACS & 5.48 & 1.97 & 1.60 & 22.20 \\
\hline $\begin{array}{l}\text { Population } \\
\text { Pon }\end{array}$ & ACS & 184547.90 & 439370.80 & 41933.00 & 8308163.00 \\
\hline Population change ( $\%$ change from year 2000 ) & ACS & 11.51 & 23.56 & -53.91 & 272.82 \\
\hline Median household income (converted to year 2000 dollars) & ACS & 37568.77 & 12219.11 & 17211.60 & 95012.95 \\
\hline $\begin{array}{l}\text { Ethnic fractionation }=\mathbf{1}-\sum_{i}^{j}\left(\boldsymbol{R a c e}_{\boldsymbol{i}}\right)^{2} \text { (where Race } i \text { denotes the share of population identified as } \\
\text { race } i \text {, including white, black, Hispanic, Asian and Pacific Islander, and American Indian. Ranges } \\
\text { from 0-1, with higher values indicating greater ethnic heterogeneity.) }\end{array}$ & ACS & 0.49 & 0.15 & 0.05 & 0.95 \\
\hline Policy conservatism index (Higher values indicate that citizens prefer more conservative policies) & $\begin{array}{l}\text { Tausanovitch and } \\
\text { Warshaw (2014) }\end{array}$ & -0.09 & 0.28 & -1.02 & 0.65 \\
\hline $\begin{array}{l}\text { capita expenditure in all cities for subfunction } i, \mathrm{~N}_{i} \text { is the number of cities performing subfunction } i, \mathrm{~F}_{i} \\
\text { is performance of subfunction } i \text {, which is } 1 \text { if city performs subfunction } i \text {, and } 0 \text { if city does not } \\
\text { perform subfunction } i \text {. See Clark and Fergusson } 1981 ; 1 \text {-year lag) }\end{array}$ & CoG, ASSLGF & 6.01 & 26.06 & 0.16 & 530.96 \\
\hline Mayor-council government (1-mayor-council, 0-council-manager) & ICMA & 0.37 & 0.48 & 0.00 & 1.00 \\
\hline \multicolumn{6}{|l|}{ Instruments } \\
\hline 1972 tax HHI & $\mathrm{CoG}$ & 0.53 & 0.28 & 0.00 & 0.99 \\
\hline 1972 nontax HHI & CoG & 0.66 & 0.20 & 0.00 & 0.99 \\
\hline 1972 expanded nontax HHI & $\mathrm{CoG}$ & 0.72 & 0.19 & 0.00 & 1.00 \\
\hline $\begin{array}{l}\text { State initiative law index ( } 0 \text {-state law does not allow all city (or equivalent) governments to have the } \\
\text { initiative, } 1 \text {-allows only some city governments, } 2 \text {-allows all city governments) }\end{array}$ & $\begin{array}{l}\text { Internet search of } \\
\text { relevant state law }\end{array}$ & 1.53 & 0.63 & 0.00 & 2.00 \\
\hline
\end{tabular}

Note: Audited reports - Comprehensive Annual Financial Reports 2006-2012; CoG - Census of Governments 2007 and 2012; ASSLGF - Annual Survey of State and Local

Government Finances 2005-2006, 2008-2011; ACS - American Community Survey 2006 to 2012; ICM - International City/County Management Association Government Form Survey 2001, 2006 and 2011; FHFA - U.S. Federal Housing Finance Agency 2005-2012. The summary statistics presented in this table are based on actual values of the variables. 
TABLE 2

Results of Least Squares Dummy Variable Regression

\begin{tabular}{|c|c|c|c|c|c|c|c|c|c|c|c|c|}
\hline \multirow{3}{*}{ Independent Variables } & \multicolumn{2}{|c|}{ PANEL 1 } & \multicolumn{2}{|c|}{ PANEL 2} & \multirow{2}{*}{\multicolumn{2}{|c|}{$\begin{array}{l}\text { PANEL 3 } \\
\text { rating Ratio }\end{array}$}} & \multicolumn{2}{|c|}{ PANEL 4} & \multicolumn{2}{|c|}{ PANEL 5 } & \multicolumn{2}{|c|}{ PANEL 6 } \\
\hline & \multicolumn{4}{|c|}{ Dependent Variable: General Fund Operating Ratio } & & & \multicolumn{6}{|c|}{ Dependent Variable: General Fund Unreserved Balance Ratio } \\
\hline & Coef. & S.E. & Coef. & S.E. & Coef. & S.E. & Coef. & S.E. & Coef. & S.E. & Coef. & S.E. \\
\hline $\begin{array}{l}\text { Diversification Measures } \\
\text { Tax HHI (1-year lag) } \\
\text { Non-tax HHI (1-year lag) } \\
\text { Expanded non-tax HHI (1-year lag) }\end{array}$ & 0.043 & 0.031 & -0.020 & 0.028 & -0.019 & 0.031 & -0.058 & 0.031 & -0.020 & 0.036 & -0.060 & 0.036 \\
\hline \multicolumn{13}{|l|}{ Controls } \\
\hline Housing price index (1-year lag) & $0.000 * *$ & 0.000 & $0.000^{* *}$ & 0.000 & $0.000 * *$ & 0.000 & $0.000 * *$ & 0.000 & $0.000 *$ & 0.000 & $0.000 * *$ & 0.000 \\
\hline$\%$ change in housing price index (1-year lag) (log) & 0.018 & 0.019 & 0.019 & 0.019 & 0.019 & 0.019 & 0.029 & 0.022 & 0.028 & 0.022 & 0.028 & 0.022 \\
\hline Private sector employment & 0.001 & 0.001 & 0.001 & 0.001 & 0.001 & 0.001 & 0.001 & 0.001 & 0.001 & 0.001 & 0.001 & 0.001 \\
\hline Unemployment rate & 0.003 & 0.002 & 0.003 & 0.002 & 0.003 & 0.002 & -0.003 & 0.003 & -0.004 & 0.003 & -0.003 & 0.003 \\
\hline Population $(\log )$ & 0.009 & 0.006 & 0.010 & 0.006 & 0.010 & 0.006 & $-0.042 * * *$ & 0.006 & $-0.043 * * *$ & 0.006 & $-0.042 * * *$ & 0.006 \\
\hline Population change $(\log )$ & 0.017 & 0.016 & 0.020 & 0.016 & 0.020 & 0.016 & $0.095 * * *$ & 0.024 & $0.092 * * *$ & 0.024 & $0.093 * * *$ & 0.024 \\
\hline Median household income & $0.000 * * *$ & 0.000 & $0.000 * * *$ & 0.000 & $0.000 * * *$ & 0.000 & $0.000 *$ & 0.000 & $0.000 *$ & 0.000 & $0.000 *$ & 0.000 \\
\hline Ethnic fractionation & $-0.146 * * *$ & 0.034 & $-0.148 * * *$ & 0.034 & $-0.149 * * *$ & 0.034 & -0.010 & 0.037 & -0.005 & 0.037 & -0.005 & 0.037 \\
\hline Policy conservatism index & 0.024 & 0.018 & 0.021 & 0.018 & 0.022 & 0.018 & $0.070 * *$ & 0.021 & $0.072 * * *$ & 0.021 & $0.073 * * *$ & 0.021 \\
\hline Dependence on IGR (1-year lag) (log) & $0.040 * * *$ & 0.007 & $0.040 * * *$ & 0.007 & $0.040 * * *$ & 0.007 & 0.012 & 0.008 & 0.011 & 0.008 & 0.011 & 0.008 \\
\hline Functional performance index (1-year lag) (log) & -0.005 & 0.009 & -0.005 & 0.009 & -0.005 & 0.009 & -0.003 & 0.008 & -0.004 & 0.008 & -0.004 & 0.008 \\
\hline Mayor-council government & -0.020 & 0.011 & -0.020 & 0.010 & -0.020 & 0.010 & -0.008 & 0.012 & -0.009 & 0.012 & -0.010 & 0.012 \\
\hline Year Dummies & Yes & & Yes & & Yes & & Yes & & Yes & & Yes & \\
\hline State Dummies & Yes & & Yes & & Yes & & Yes & & Yes & & Yes & \\
\hline Constant & $0.589 * * *$ & 0.129 & $0.600 * * *$ & 0.129 & $0.602 * * *$ & 0.129 & 0.044 & 0.144 & 0.044 & 0.143 & 0.063 & 0.144 \\
\hline $\mathrm{N}$ & \multicolumn{2}{|c|}{3983} & \multicolumn{2}{|c|}{3983} & \multicolumn{2}{|c|}{3983} & \multicolumn{2}{|c|}{3983} & \multicolumn{2}{|c|}{3983} & \multicolumn{2}{|c|}{3983} \\
\hline $\mathrm{R}-\mathrm{Sq}$. & \multicolumn{2}{|c|}{0.298} & \multicolumn{2}{|c|}{0.297} & \multicolumn{2}{|c|}{0.297} & \multicolumn{2}{|c|}{0.209} & \multicolumn{2}{|c|}{0.208} & & \\
\hline & PAN & & PAN & & PAN & & PANK & & PAN & & PAN & \\
\hline Independent Variables & & $\operatorname{dent} V$ & ble: Gover & ent-Wic & perating $\mathbf{R}$ & & Dependent & ariable: & vernment- & de Unre & icted Net Po & on Ratio \\
\hline & Coef. & S.E. & Coef. & S.E. & Coef. & S.E. & Coef. & S.E. & Coef. & S.E. & Coef. & S.E. \\
\hline $\begin{array}{l}\text { Diversification Measures } \\
\text { Tax HHI (1-year lag) } \\
\text { Non-tax HHI (1-year lag) } \\
\text { Expanded non-tax HHI (1-year lag) }\end{array}$ & $-0.034 *$ & 0.017 & 0.007 & 0.019 & $0.044 *$ & 0.019 & $-0.200 * *$ & 0.067 & $0.306 * * *$ & 0.071 & $0.424 * * *$ & 0.068 \\
\hline Controls & & & & & & & & & & & & \\
\hline Housing price index (1-year lag) & $0.000 * *$ & 0.000 & $0.000 * *$ & 0.000 & $0.000 * * *$ & 0.000 & -0.001 & 0.000 & -0.001 & 0.000 & -0.001 & 0.000 \\
\hline$\%$ change in housing price index (1-year lag) $(\log )$ & $0.030 * *$ & 0.012 & $0.029 *$ & 0.012 & $0.029 *$ & 0.012 & 0.054 & 0.043 & 0.039 & 0.043 & 0.045 & 0.043 \\
\hline Private sector employment & $0.001^{*}$ & 0.001 & $0.001 *$ & 0.001 & $0.001 *$ & 0.000 & $0.010 * * *$ & 0.002 & $0.010 * * *$ & 0.002 & $0.010 * * *$ & 0.002 \\
\hline Unemployment rate & $-0.006^{* * * *}$ & 0.002 & $-0.006 * * *$ & 0.002 & $-0.006 * * *$ & 0.002 & -0.008 & 0.006 & -0.008 & 0.006 & -0.009 & 0.006 \\
\hline Population $(\log )$ & $-0.012 * * *$ & 0.003 & $-0.013 * * *$ & 0.003 & $-0.013 * * *$ & 0.003 & $-0.112 * * *$ & 0.014 & $-0.123 * * *$ & 0.014 & $-0.125 * * *$ & 0.014 \\
\hline Population change (log) & 0.005 & 0.012 & 0.003 & 0.012 & 0.002 & 0.012 & $0.096^{*}$ & 0.043 & 0.075 & 0.044 & 0.077 & 0.043 \\
\hline Median household income & $0.000^{* *}$ & 0.000 & $0.000^{* *}$ & 0.000 & $0.000 * *$ & 0.000 & $0.000 * * *$ & 0.000 & $0.000 * * *$ & 0.000 & $0.000 * * *$ & 0.000 \\
\hline Ethnic fractionation & 0.000 & 0.020 & 0.002 & 0.020 & 0.001 & 0.019 & 0.101 & 0.088 & 0.102 & 0.088 & 0.105 & 0.089 \\
\hline Policy conservatism index & -0.010 & 0.010 & -0.008 & 0.010 & -0.008 & 0.010 & $0.111^{*}$ & 0.045 & $0.133 * *$ & 0.044 & $0.123 * * *$ & 0.044 \\
\hline Dependence on IGR (1-year lag) (log) & $-0.019 * * *$ & 0.004 & $-0.019 * * *$ & 0.004 & $-0.019 * * *$ & 0.004 & -0.028 & 0.016 & -0.023 & 0.016 & -0.027 & 0.016 \\
\hline Functional performance index (1-year lag) (log) & 0.000 & 0.004 & -0.001 & 0.004 & -0.001 & 0.004 & 0.004 & 0.016 & 0.006 & 0.017 & 0.003 & 0.017 \\
\hline Mayor-council government & -0.007 & 0.006 & -0.007 & 0.006 & -0.007 & 0.006 & $-0.099 * * *$ & 0.026 & $-0.095^{* * *}$ & 0.026 & $-0.094 * * *$ & 0.026 \\
\hline Year Dummies & Yes & & Yes & & Yes & & Yes & & Yes & & Yes & \\
\hline State Dummies & Yes & & Yes & & Yes & & Yes & & Yes & & Yes & \\
\hline Constant & $1.073 * * *$ & 0.078 & $1.067 * * *$ & 0.078 & $1.051 * * *$ & 0.077 & 0.448 & 0.302 & 0.338 & 0.301 & 0.253 & 0.298 \\
\hline $\mathrm{N}$ & & & & & & & & & & & & \\
\hline R-Sq. & & & 0. & & & & 0.4 & & 0. & & & \\
\hline
\end{tabular}

Note: Standard errors (S.E) are heteroskedasticity- and autocorrelation-robust (Kernel-Bartlett bandwidth $=3$ ). The base state is Alabama, and the base year is 2006 . Results for state and year dummies are not shown because of space consideration. $* * *$ significant at $.1 \%$, ** at $1 \%$, and $*$ at $5 \%$, two-tailed tests. 
TABLE 3

Results of Instrumental Variable Regression (Full results are not shown because of space consideration.)

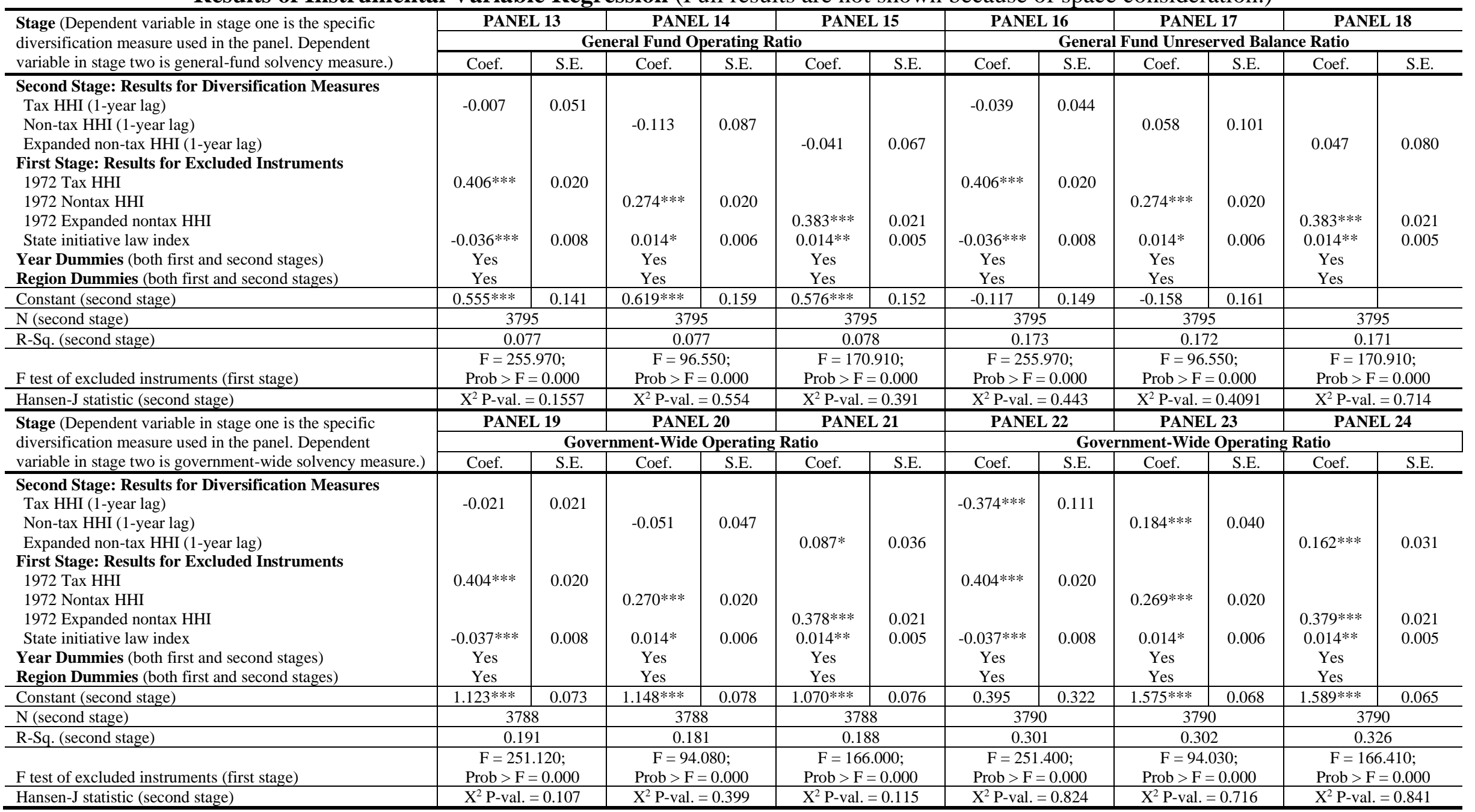

Hansen-J statistic (second stage)

$\mathrm{X}^{2} \mathrm{P}$-val. $=0.107 \quad \mathrm{X}^{2} \mathrm{P}$-val. $=0.399$

$\mathrm{X}^{2} \mathrm{P}$-val. $=0.115$

Note: Standard errors (S.E) are heteroskedasticity- and autocorrelation-robust (Kernel-Bartlett bandwidth $=3$ ). The base region is the West, and the base year is 2006 . Results for region and year

dummies are not shown because of space consideration. *** significant at $.01 \%$, ** at $1 \%$, and * at $5 \%$, two-tailed tests. When reading the results for the instruments in the first stage of the IV

regression, note that the dependent variable in the first stage is the specific diversification measure used in the panel. For example, in Panel 20, the dependent variable in the first stage is the non-tax HH (lagged by a year, so the data are from 2005-2011). The results for the instruments in the first stage indicate that the 1972 non-tax HHI has a positive and highly statistically significant relationship with he 2005-2011 non-tax HHI, and the State initiative law index also has a positive and highly statistically significant relationship with the $2005-2011$ non-tax HHI. 


\section{FIGURE 1}

\section{Predicted Effects of Different Diversification Measures}

(Based on results from LSDV models in table 2 where HHI measures are statistically significant. All control variables are set at their means.)
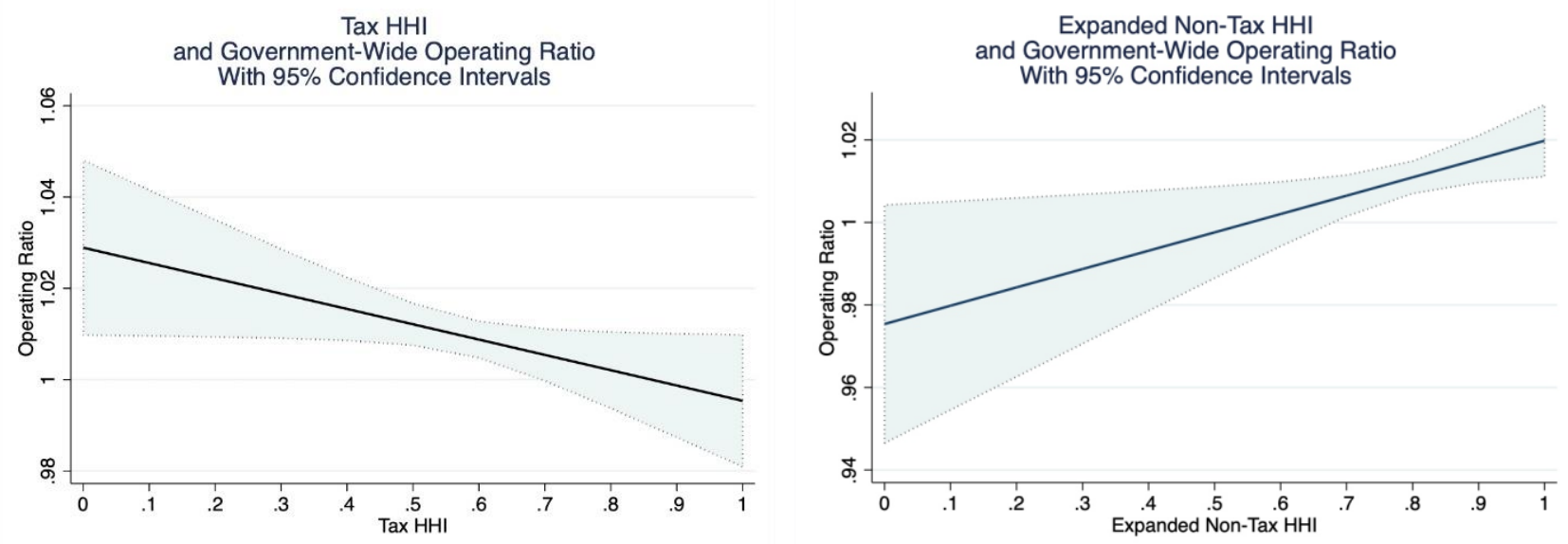

Tax HHI

and Government-Wide Unrestricted Net Position Ratio

With $95 \%$ Confidence Intervals
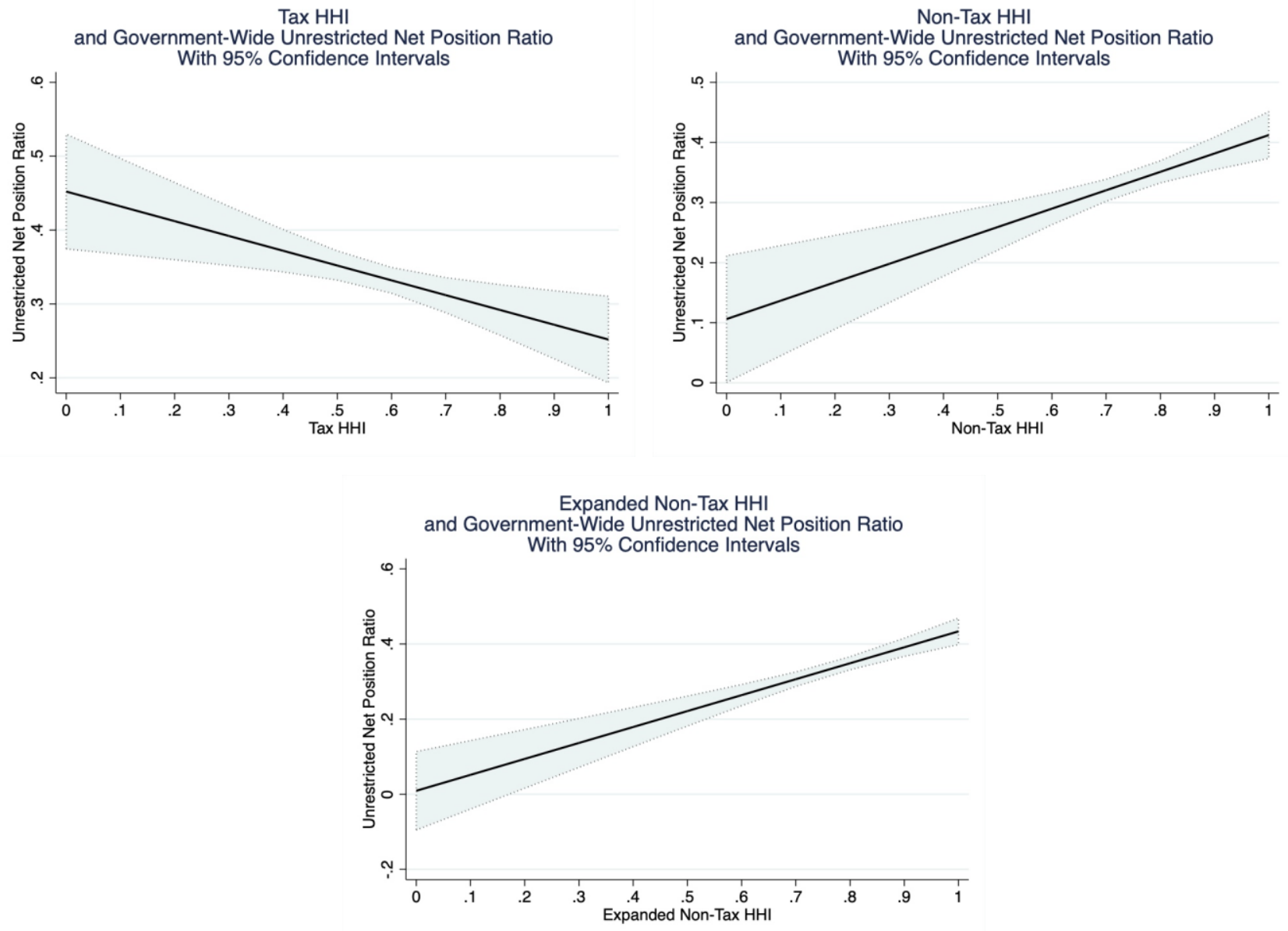